\title{
ANTI-CORRUPTION EDUCATION IN THE FAMILY, COMMUNITY, SCHOOL AND STATE
}

\author{
Alil Rinenggo ${ }^{1}$, Intan Kusumawati ${ }^{2}$, Zaenul Stiyawan ${ }^{3}$, Sutiyono $^{4}$ \\ ${ }^{1}$ Pendidikan Pancasila dan Kewarganegaraan, Universitas Darul Ulum Islamic Centre \\ Sudirman GUPPI, ${ }^{2}$ Pendidikan Pancasila dan Kewarganegaraan, Universitas \\ Cokroaminoto Yogyakarta, ${ }^{3}$ SMP Negeri 1 Margoyoso, ${ }^{4}$ Pendidikan Guru Sekolah Dasar, \\ Universitas Nahdatul Ulama Yogyakarta \\ ${ }^{1}$ Email: rinenggoalil@gmail.com \\ ${ }^{2}$ Email: intankusumawati1978@gmail.com \\ ${ }^{3}$ Email: zaenulstiyawan@gmail.com \\ ${ }^{4}$ Email: sutiyono@unu-jogja.ac.id
}

\begin{abstract}
ABSTRAK
Penulisan bertujuan untuk mendeskripsikan peran dan strategi keluarga, masyarakat, sekolah, dan negara dalam pendidikan antikorupsi. Teknik pengumpulan data menggunakan studi literatur. Hasil kajian menunjukkan bahwa pendidikan antikorupsi di lingkungan keluarga, sekolah, masyarakat dan negara harus diwujudkan secara bersama-sama. Keluarga memiliki peran dalam mendidik anak-anak melalui keteladanan, pembiasaan, dan dialog. Strategi yang digunakan yaitu menjalankan fungsi keagamaan, sosial-budaya, sosialisasi dan pendidikan, serta ekonomi. Masyarakat perlu mengenal korupsi untuk perbaikan birokrasi, mengetahui hak dan kewajiban sebagai warga negara yang cerdas dan baik, kerja sama dan komitmen yang utuh. Sekolah perlu merancang modul pembelajaran dengan mengembangkan nilai-nilai antikorupsi, seperti nilai inti, nilai sikap, dan nilai etos kerja. Strategi yang dilakukan sekolah yaitu pengembangan model pembelajaran PPKn antikorupsi berbasis lingkungan melalui cooperative learning. Negara perlu menerapkan budaya malu di lingkungan pemerintahan, memasukkan pendidikan antikorupsi di pendidikan dasar sampai dengan pendidikan tinggi, dan merumuskan sanksi sosial dalam tindak pidana korupsi.
\end{abstract}

Kata kunci: Pendidikan, antikorupsi, lingkungan

This work is licensed under a Creative Commons Attribution-ShareAlike 4.0 CC BY-SA International License.

\begin{abstract}
This writing aims to describe the roles and strategies of the families, communities, schools, and state for anti-corruption education. Techniques for data collection was literature studies. The results of the study show that anti-corruption education in the family, school, community and state must be put into effects together. The role of the families is to educate children by example, habits, and dialogue. The employed strategy is to make use of the religion, society and culture, socialization and education, as well as the economy. People need to learn about corruption to improve the bureaucracy, understand their rights and obligations as smart and good citizens, and fully cooperate and commit. Schools need to design learning modules by developing anticorruption values, such as core values, attitude values, and work ethic values. The strategy used by the school is to develop an environment-based anti-corruption PPKn learning model through cooperative learning. The state needs to implement a culture of shame in the government, include anti-corruption education in basic to higher education, and formulate social sanctions for corruption.
\end{abstract}

Keywords: Education, anti-corruption, environment 


\section{PENDAHULUAN}

Korupsi merupakan perbuatan melawan hukum yang dikategorikan sebagai kejahatan luar biasa atau dikenal istilah extraordinary crime. Namun praktik korupsi masih marak terjadi hampir setiap tahun sejak bergulirnya era reformasi sampai sekarang. Sesuai tuntutan era reformasi, adanya tata kelola pemerintahan yang baik, bersih, dan transparan belum berjalan sebagaimana mestinya. Padahal regulasi terkait pemberantasan korupsi sudah ditetapkan oleh pemerintah dengan hadirnya UU No. 19 tahun 2019 tentang Perubahan Kedua Atas UU No. 30 tahun 2002 tentang Komisi Pemberantasan Tindak Pidana Korupsi. Dari aspek hukum, hadirnya undang-undang tersebut sebenarnya sudah memberikan upaya pencegahan dan penindakan terhadap pelaku korupsi. Pokok permasalahan yang ada yaitu eksekusi hukuman yang diberikan oleh hakim terkadang masih ringan sebagai kejahatan luar biasa, sehingga tidak memberikan efek jera bagi pelaku korupsi. Hukuman yang diberikan seringkali tidak sesuai tuntutan jaksa atau bahkan lebih rendah dari sanksi hukuman yang diatur di dalam undang-undang.

Akar masalah lain dilihat dari aspek sosial-budaya, korupsi telah menjadi "kebiasaan" di tengah msyarakat. Praktik korupsi sudah ada sejak zaman pemerintahan Belanda di Indonesia. Hal itu terlihat dari laporan VOC terkait korupsi yang terjadi di berbagai daerah. Pelakunya yaitu bupati atau orang-orang di internal Kolonial Belanda. Kebiasaan yang dilakukan pemimpin atau calon pemimpin daerah dalam memberikan gratifikasi sudah ada di era saat itu (Suryandari, 2021). Pola yang demikian masih terjadi antara anggota legislatif, pejabat pemerintah, pihak swasta, dan di lingkungan partai. Masalah "kebiasaan" yang sudah "mandarah daging" sulit untuk diubah menjadi budaya yang antikorupsi.

Praktik korupsi di Indonesia semakin hari terlihat semakin memprihatinkan. Korupsi menjerat para pejabat pemerintah tingkat lokal sampai dengan tingkat nasional. Mulai dari tingkat bawah, misalnya dana desa yang seharusnya untuk kepentingan masyarakat desa dikorupsi oleh kepala desa untuk menguntungkan diri sendiri. Kasus tersebut terjadi di Cianjur, Jawa Barat. Tersangka menyelewengkan dana desa yang diperuntukkan BUMDes dengan kerugian negara sebesar Rp 362 juta (Taufiqurrahman, 2021). Di tingkat daerah kabupaten, korupsi terjadi di akhir bulan Agustus tahun 2021, menyeret Bupati Probolinggo dan suami beserta beberapa camat yang diduga menerima suap terkait jual beli jabatan kepala desa (Rofiq, 2021). Selanjutnya di tingkat nasional, mantan Menteri Sosial yaitu Juliari P. Batubara tersandung kasus korupsi terkait suap bantuan sosial untuk menangani pandemi Covid-19 di wilayah Jabodetabek pada tahun 2020 (Kamil, 2021). Kasus-kasus tersebut menandakan bahwa praktik korupsi masih masif terjadi di lingkungan masyarakat, bangsa dan negara yang belum mampu diatasi secara optimal.

Data menunjukkan bahwa jumlah kasus tindak pidana korupsi yang ditangani oleh KPK antara tahun 2004 sampai dengan bulan Mei 2020, sebanyak 297 kasus korupsi dilakukan oleh pihak swasta. Selanjutnya kasus korupsi sebanyak 257 yang dilakukan oleh anggota DPR. Perkara korupsi yang sering dilakukan oleh pihak swasta yaitu perkara suap (Budiman, 2021). Perkara suap 
yang terjadi melibatkan pihak swasta dengan pemegang kekuasaan terkait kepentingan bisnis. Hal ini yang perlu menjadi perhatian dan pengawasan KPK dalam pemberantasan korupsi.

Adanya perubahan revisi Undang-Undang tentang Komisi Pemberantasan Tidak Pidana Korupsi justru berpeluang melemahkan KPK dalam pemberantasan korupsi. Pertama, tindak pidana korupsi menggunakan hukum acara pidana biasa, sehingga implikasinya korupsi dianggap kejahatan biasa, bukan luar biasa. Kedua, peran KPK bisa semakin menurun karena sebelumnya sebagai lembaga yang independen, sekarang berada di bawah lembaga pemerintah (bagian dari eksekutif). Ketiga, munculnya dewan pengawas memberikan pengawasan terlalu dominan, tidak sekadar mengawasi dan mengevaluasi namun juga masuk dalam penanganan teknis perkara. Hal ini dianggap tidak efektif dan dijadikan alat intervensi (Putri, 2019). Meskipun dalam pasal 3 UU KPK terdapat kalimat bahwa KPK bersifat independen dan bebas dari pengaruh manapun, namun hal tersebut menjadi tidak berarti karena Dewan Pengawas direkrut oleh Presiden dan secara struktural berada di atas Komisioner. Ini dikhawatirkan akan menghambat pemberantasan tindak pidana korupsi terhadap oknum tertentu (Syahuri, 2021).

Berdasarkan data dari BPS (Badan Pusat Statistik) tahun 2021, Indeks Perilaku Anti Korupsi (IPAK) Indonesia tahun 2021 sebesar 3,88 pada skala 0 sampai 5. Angka tersebut lebih tinggi dibandingkan capaian 2020 sebesar 3,84. Kriteria penilaian perilaku antikorupsi yaitu nilai indeks yang semakin mendekati angka 5 menunjukkan bahwa masyarakat berperilaku semakin antikorupsi. Sebaliknya, nilai indeks yang semakin mendekati angka 0 menunjukkan bahwa masyarakat berperilaku semakin permisif terhadap korupsi. Perkembangan Perilaku Anti Korupsi di Indonesia sudah mengalami kenaikan sejak 2012 sampai 2021, dapat dilihat pada gambar 1 sebagai berikut.

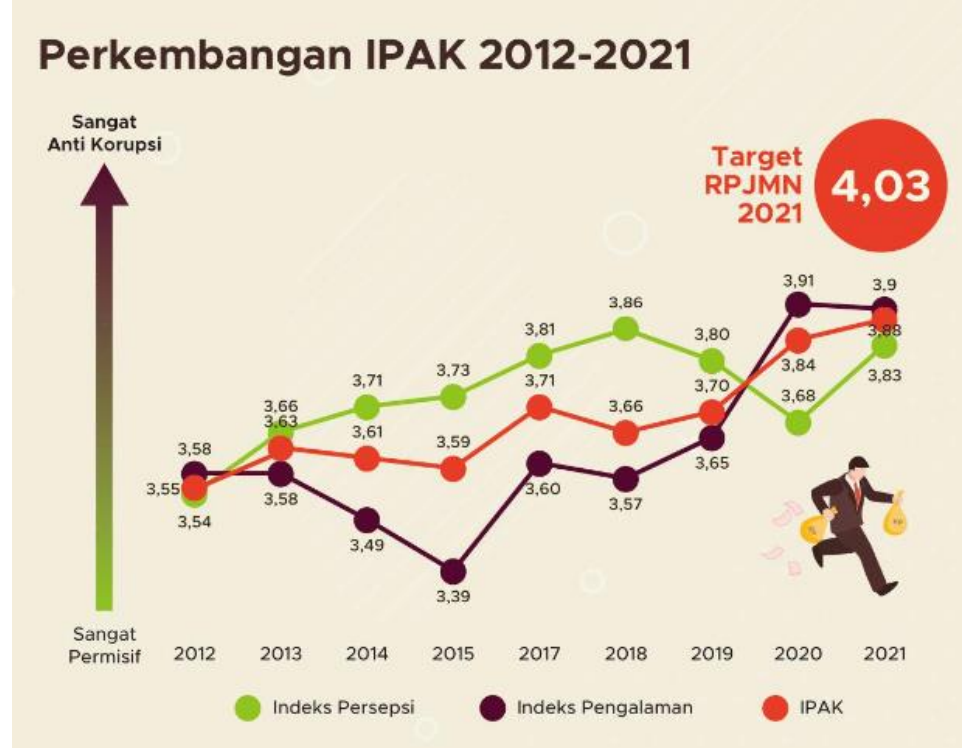

Gambar1. Perkembangan IPAK 2012-2021

(Sumber: BPS, 2021)

Dilihat dari gambar 1 tersebut, kesadaran antikorupsi masyarakat Indonesia relatif meningkat, meskipun terjadi fluktuasi antara tahun 2014-2020. Meskipun adanya kenaikan, namun 
capaian yang diperoleh pada tahun 2021 masih cukup jauh dari target. Pada tahun 2021, IPAK Indonesia ditargetkan berada pada skor 4,03.

Pemberantasan perilaku atau kasus korupsi tidak bisa dibebankan hanya pada lembaga KPK (Komisi Pemberantasan Korupsi). Semua komponen dalam lingkup keluarga, masyarakat, sekolah, dan negara memiliki kewajiban untuk membantu KPK dalam mencegah dan menanggulangi pemberantasan korupsi. Sinergisitas antar komponen tersebut menjadi vital dalam menciptakan budaya antikorupsi. Dimulai dari hal yang sederhana yaitu lingkungan keluarga. Orang tua bisa menanamkan nilai-nilai antikorupsi dengan pembiasaan dan keteladanan yang baik. Namun sering terjadi justru perilaku korupsi masih terjadi di lingkungan keluarga, misalnya, orang tua memberikan uang atau hadiah kepada anak ketika mau belajar atau mendapatkan rangking atau prestasi di sekolah. Di lingkungan masyarakat juga masih terjadi perilaku korupsi, misalnya money politik hampir terjadi setiap adanya Pilkades dan Pemilu. Kemudian di lingkungan sekolah masih ditemukan siswa yang menyontek, membolos, dan kurang disiplin. Di lingkungan negara juga masih terjadi kasus suap di lembaga legislatif dan eksekutif. Selanjutnya Hasanah (2019: 307) menjelaskan bahwa membangun kepribadian antikorupsi siswa sebagai agen perubahan bagi kehidupan masyarakat dan negara yang dilindungi dari ancaman korupsi tetap jauh dari harapan. Menyikapi hal tersebut, semua komponen harus mengoptimalkan peran dan strategi dalam mencegah dan menanggulangi perilaku atau kasus korupsi agar bangsa Indonesia bisa memiliki jati diri, etika dan integritas yang tinggi.

Pendidikan merupakan langkah strategis untuk menghasilkan agen antikorupsi dalam pencegahan korupsi. Pendidikan menawarkan berbagai cara untuk menanamkan dan mempraktikkan nilai-nilai antikorupsi kepada peserta didik sebagai nilai-nilai pribadi dan sosial (Handoyo, 2021: 2682). Pendidikan antikorupsi tidak terbatas hanya menyampaikan aspek nilai, namun yang paling urgen yaitu diperlukan strategi khusus agar nilai-nilai antikorupsi bisa dikonstruksi dalam diri anak, masyarakat, dan pejabat negara. Misalnya, dalam lingkup keluarga, anak diajak untuk merefleksikan sikap dalam kehidupan sehari-hari yang melanggar nilai antikorupsi beserta dampak atau akibat yang akan diterima. Refleksi tersebut sedikit akan membangun rasa afektif anak untuk menghindari perilaku korupsi. Penelitian dari Utami, dkk., 2016: 7) menyatakan bahwa ada pengaruh yang positif dan signifikan antara pendidikan karakter antikorupsi dalam keluarga terhadap karakter antikorupsi pada remaja. Berangkat dari penelitian tersebut, penulis tertarik untuk mengkaji dan membahas mengenai peran dan strategi keluarga, sekolah, masyarakat, dan negara dalam pendidikan antikorupsi, sehingga diharapkan dapat menambah wawasan secara teoretis dan praktis dalam pencegahan dan penanganan perilaku atau kasus korupsi di Indonesia. 


\section{METODE PENELITIAN}

Data dikumpulkan melalui studi literatur dengan pendekatan kualitatif. Data digali dari artikel ilmiah, buku, dan berita online yang relevan dengan kajian pendidikan antikorupsi. Langkah pertama, penulis membaca keseluruhan sumber data yang sudah diperoleh. Kedua, menemukan poin penting berupa konsep dan gagasan yang ada kaitan dengan peran dan strategi dalam pendidikan antikorupsi. Ketiga, penulis menyusun gagasan atau konsep yang ditemukan dengan mengkategorikan sesuai sub tema yang akan dibahas. Keempat, mendeskripsikan hasil temuan studi literatur dengan cara memadukan ide penulis dan konsep yang relevan dengan pendidikan antikorupsi di lingkungan keluarga, sekolah, masyarakat, dan negara.

\section{HASIL DAN PEMBAHASAN \\ Peran dan Strategi Keluarga dalam Pendidikan Antikorupsi}

Keluarga berperan utama dalam tumbuh kembangnya kepribadian anak. Keluarga merupakan tempat pertama bagi anak dalam mendapatkan kasih sayang dan pendidikan karakter dari orang tua. Sesuai dengan pernyataan Putra, dkk., (2018: 486) bahwa keluarga sebagai agen sosialisasi dan pendidikan pertama bagi anak, harus menjadi tempat sosialisasi dan pendidikan antikorupsi. Anak dibesarkan melalui nilai-nilai kebaikan dan budi pekerti yang dimiliki oleh orang tua. Sebelum menanamkan pendidikan antikorupsi, orang tua perlu mengetahui hakikat korupsi dan nilai-nilai antikorupsi secara mendalam. Setelah itu, orang tua perlu mengambil peran sebagai pendidik. Orang tua tidak sekadar mengajarkan namun memberikan keteladanan bagi anak, melalui sikap yang jujur (misalnya: tidak mau menerima money politik, berpenampilan sederhana, memperlakukan anak-anak secara adil tanpa membedakan, tidak memberi janji kepada anak disertai hadiah atau uang untuk melakukan sesuatu, berani menolak permintaan anak ketika tidak sesuai kebutuhan mereka, memberi tanggung jawab sesuai kemampuan anak, bekerja keras, melibatkan anak dalam bermusyawarah sehingga anak dapat menyampaikan usulan atau berpikir kritis. Pendidikan antikorupsi sebagai pembudayaan menjadi penting karena mampu meletakkan dasar-dasar karakter yang anti terhadap korupsi pada anak sebagai modal insani bagi kelangsungan hidup di masyarakat dan negara (Atmadja, 2015: 87).

Pencegahan korupsi dapat dilakukan dengan memperkuat ikatan individu dengan kelompok, dengan kunci utamanya yaitu keluarga dan sistem pendidikan (Widhiasthini, et al. 2020: 2372). Penanaman nilai antikorupsi kepada anak oleh orang tua dapat diterapkan dengan metode teladan, metode pembiasaan dan metode dialog. Beberapa metode tersebut berjalan efektif sehingga anak dapat mengaktualisasikan nilai pendidikan antikorupsi di lingkungannya (Ratnasari \& Sarmini, 2017: 425). Orang tua dapat membiasakan anak dengan berbagai aktivitas atau kegiatan yang dilakukan dalam lingkungan keluarga, misalnya suka bersedekah atau berbagi makanan kepada orang yang membutuhkan. Secara praktis, anak akan terbiasa berbagi dengan siapapun dan dapat 


\section{AoEJ: Academy of Education Journal \\ Vol. 13 No 1 Tahun 2022}

menumbuhkan sikap empati kepada orang lain. Mustahil bagi anak untuk melakukan perilaku korupsi karena sejak kecil sudah dididik untuk berbagi dengan orang lain. Selanjutnya metode dialog, orang tua bisa berdialog dengan anak mengenai permasalahan yang dialami anak, sehingga anak akan merasa mendapatkan perhatian dan terbiasa terbuka untuk mencurahkan masalah yang dihadapi. Hal ini akan melatih kejujuran pada anak dan membuka diskusi untuk pemecahan masalah. Pola asuh dan nilai-nilai yang diajarkan keluarga akan berpengaruh pada kepribadian dan kehidupan anak sehingga menjadi benteng dari perilaku korupsi (Isgiyanti, dkk., 2016: 27).

Penanaman nilai antikorupsi didukung oleh beberapa faktor antara lain komitmen orang tua dalam mengajarkan nilai-nilai antikorupsi dan nilai agama bagi anak, lingkungan yang agamis, dan pendidikan orang tua (Waskito \& Pambudi, 2018: 182). Orang tua harus memiliki komitmen dari awal bahwa nilai tanggung jawab, kemandirian, dan kejujuran menjadi prioritas dalam pembentukan karakter antikorupsi pada anak. Komunikasi antara pihak keluarga menjadi penting karena anak tidak mesti berinteraksi dengan keluarga kecil saja namun juga dengan keluarga besar lainnya. Orang tua bisa mengedukasi perilaku antikorupsi dengan tidak mengambil barang milik teman, jujur saat mengerjakan tugas, terbuka dalam mengalami masalah, berbicara jujur, dan hidup sederhana. Orang tua perlu menanamkan sikap rajin, kemauan untuk mencoba, menikmati setiap proses yang sulit dan bekerja keras untuk anak-anak sehingga tidak ada keinginan yang instan (Thoomaszen \& Tameon, 2018: 211). Selanjutnya yaitu meletakkan ajaran agama sebagai fondasi yang kuat untuk diilhami dan diyakini kebenarannya sebagai makhluk ciptaan Tuhan Yang Maha Esa. Setiap agama pasti mengajarkan kebaikan khususnya nilai kejujuran menjadi nilai yang umum diajarkan kepada pemeluk agama. Orang tua perlu menyadari bahwa anak sejak kecil wajib diberikan keteladanan untuk mengamalkan ajaran agama yang dianutnya. Dimulai dari yang sederhana, misalnya selalu berdoa sebelum beraktivitas, bersedekah, dan beribadah lainnya. Ketika sudah menginjak usia remaja kemudian diberi pemahaman terkait alasan harus menjalankan ajaran agama, dampak ketika menyimpang dari ajaran agama, serta memperkuat keyakinan anak untuk berbuat yang baik sesuai agama. Faktor yang lain yaitu lingkungan agamis, orang tua perlu memilihkan sekolah atau tempat menimba ilmu yang memiliki lingkungan atau budaya yang agamis. Dengan demikian, diharapkan anak akan tumbuh dengan kepribadian yang memiliki karakter religius atau taat pada ajaran agama. Nilai-nilai antikorupsi ditanamkan dalam pendidikan antikorupsi perlu diperkuat dengan ajaran agama (Atmadja, 2015: 86).

Strategi yang paling utama dalam pendidikan antikorupsi dalam keluarga yaitu menjalankan beberapa fungsi dalam keluarga. Menurut BKKBN (Badan Kependudukan dan Keluarga Berencana Nasional) dan sesuai dengan Peraturan Pemerintah No. 21 Tahun 1994 tentang Penyelenggaraan Pembangunan Keluarga Sejahtera, terdapat delapan fungsi utama di dalam keluarga, yaitu: fungsi keagamaan, fungsi sosialisasi dan pendidikan, fungsi cinta kasih, fungsi reproduksi, fungsi perlindungan, fungsi sosial budaya, fungsi ekonomi, fungsi pelestarian 


\section{AoEJ: Academy of Education Journal}

Vol. 13 No 1 Tahun 2022

lingkungan (Hidayati, 2021: 66). Dari fungsi keluarga tersebut, penulis akan memilih beberapa fungsi untuk dibahas yang ada kaitannya dengan pendidikan antikorupsi.

Pertama, fungsi keagamaan, keluarga wajib menanamkan nilai-nilai agama kepada anak sejak kecil melalui praktik, pembiasaan dan keteladanan yang berkelanjutan. Anak harus memiliki keyakinan terhadap sikap atau perilaku yang dilakukan merupakan perintah dan larangan dari Tuhan Yang Maha Esa. Dengan demikian, anak akan berusaha jujur dan tanggung jawab terhadap diri sendiri dan orang lain. Kedua, fungsi sosial-budaya, orang tua perlu mengenalkan dan melibatkan anak dalam kegiatan/ pertunjukkan sosial-budaya. Suatu contoh di dalam lingkungan pedesaan, ada peninggalan budaya kesenian yaitu pertunjukkan wayang kulit. Anak bisa dikenalkan dan diajak untuk menonton wayang kulit. Di dalam pertunjukkan wayang kulit biasanya menceritakan tema tertentu dengan tokoh protagonis dan antagonis. Diharapkan anak akan menangkap nilai-nilai kebaikan yang harus dilakukan dan nilai keburukan yang harus dihindari. Hal lain dapat dilakukan dengan menyesuaikan kearifan lokal yang ada di masing-masing daerah yang ada kaitannya dengan nilai-nilai antikorupsi. Dalam perspektif budaya, membutuhkan berbagai nilai dan struktur yang ada di masyarakat, misalnya tokoh adat, tokoh agama, tokoh budaya pemimpin, dan masyarakat secara keseluruhan (Syarif, et al. 2020: 12185). Ketiga, fumgsi sosialisasi dan pendidikan, orang tua perlu memberikan pemahaman bahwa korupsi merupakan perbuatan tercela yang merugikan masyarakat banyak dan melanggar undang-undang. Korupsi juga termasuk perbuatan yang hanya sesaat untuk menikmati uang/barang haram, namun rasa penyesalannya akan berjalan seumur hidup. Keempat, fungsi ekonomi, orang tua harus mencukupi kebutuhan pokok anak namun tidak boleh berlebihan dalam memberikan fasilitas pada anak. Orang tua perlu memilah mana yang merupakan kebutuhan pokok dan kebutuhan sekunder, sehingga anak akan terbiasa untuk hidup sederhana atau tidak berjiwa hedonis. Selain itu, sejak kecil harus dibiasakan untuk suka menabung agar hidupnya kelak terbiasa hemat dan bisa mengelola uang dengan baik sesuai kebutuhan.

Nilai-nilai antikorupsi antara lain tanggung jawab, kejujuran, sederhana, kemandirian, disiplin, kerja keras, keberanian dan keadilan. Nilai-nilai tersebut perlu diaktualisasikan oleh masing-masing individu untuk dapat mencegah faktor eksternal. Selain memiliki nilai antikorupsi, setiap orang perlu memahami prinsip antikorupsi yang akuntabilitas, keadilan, transparansi, dan pengendalian kebijakan dalam suatu organisasi/lembaga/masyarakat. Hubungan antara prinsip dan nilai antikorupsi merupakan satu kesatuan yang tidak dapat dipisahkan dan hanya dapat ditanamkan melalui upaya pendidikan (Rawanoko, et al. 2019: 398). Penanaman nilai kejujuran terhadap anak harus didukung oleh peran serta keluarga dan masyarakat di lingkungan yang aman (Alfurkan \& Marzuki, 2019: 229). Penekanan pada aspek sosialisasi dan pengendalian diri juga ditekankan melalui pencegahan korupsi di tingkat mikro (keluarga dan pendidikan) dan tingkat makro (KPK) (Widhiasthini, 2020: 2377). 


\section{Peran dan Strategi Masyarakat dalam Pendidikan Antikorupsi}

Masyarakat memiliki peran sebagai pemegang kedaulatan tertinggi dalam negara yang mengikuti sistem pemerintahan demokrasi. Masyarakat mempunyai peran sebagai pihak yang dapat memperbaiki birokrasi, pihak yang cerdas dalam mengenal hak dan kewajiban dalam menekan praktik korupsi, dan pihak yang bisa diajak kerja sama dalam menguatkan komitmen melawan korupsi. Beberapa peran tersebut, secara aktif dan konsisten diharapkan dapat menghilangkan korupsi di negeri ini. Berikut penjelasakan mengenai keadaan kasus korupsi di Indonesia.

Korupsi seringkali berawal dari diri setiap individu dengan sifat rakus manusia. Sifat rakus ini terjadi ketika seseorang mempunyai hasrat yang besar dalam menuruti keinginannya menjadi kaya raya sekaligus tidak pernah merasa puas dengan yang diperoleh. Faktor lain yaitu gaya hidup konsumtif yang membutuhkan pendapatan yang tidak sedikit melahirkan peluang untuk melakukan hal yang bersifat negatif demi memenuhi keinginannya. Moralitas yang samakin merosot menjadikan seseorang mudah tergoda untuk melakukan tindakan amoral termasuk korupsi. Jika membuat janji tidak ditepati dan sering berbohong juga menjadi indikator kuat lahirnya tindakan korupsi ini. Beberapa tindakan kecil tersebut yang melanggar aturan biasanya menjadikan kebiasaan buruk bagi para pelakunya, sehingga kedepan apabila telah memiliki posisi, jabatan, dan kekuasaan berpotensi besar akan melakukan penyelewengan wewenang ke arah tindakan korupsi.

Pada konteks Indonesia, setiap tahun mengalami kenaikan dalam jumlah aset negara. Berdasarkan Laporan Keuangan Pemerintah Pusat (LKKP) pada tahun 2020 disebutkan bahwa nilai aset lancar yang dimiliki Indonesia mengalami kenaikkan sebesar 35,23 persen dibanding nilai per 31 Desember 2019. Sementara nilai kewajiban per 31 Desember 2020 mengalami kenaikan sebesar 24,06 persen dibandingkan nilai per 31 Desember 2019. Jika diuangkan maka kenaikan aset lancar per 31 Desember dan 31 Desember 2019 sebebar Rp665.161.112.767.725 dan Rp491.867.510.128.337. Seringkali data kenaikan jumlah aset negara dapat digambarkan pada tabel 1 sebagai berikut.

Tabel 1. Kenaikan Aset Lancar Negara

\begin{tabular}{lrrc}
\hline \multicolumn{1}{c}{ Aset Lancar } & $\begin{array}{c}\text { 31 Desember 2020 } \\
\text { (Audited) }\end{array}$ & $\begin{array}{c}\text { 32 Desember 2019 } \\
\text { (Audited) }\end{array}$ & $\begin{array}{c}\text { \% Kenaikan/ } \\
\text { (Penurunan) }\end{array}$ \\
\hline Kas dan Setara Kas & 256.923 .467 .961 .654 & 208.962 .960 .718 .114 & 22,95 \\
Uang Muka dari Rekening BUN & 11.763 .117 .361 & 5455736.715 & 115,61 \\
Investasi Jangka Pendek & 80.997 .797 .371 .759 & 10.817 .836 .834 .384 & 648,74 \\
Belanja Dibayar Dimuka dan Uang Muka & 34.421 .569 .421 .725 & 34.972 .003 .392 .136 & 1,571 \\
Belanja & & & \\
Pendapatan yang Masih Harus Diterima & 5.591 .639 .511 .588 & 3.028 .979 .606 .205 & 84,60 \\
Piutang & 126.700 .067 .094 .014 & 110.630 .183 .915 .948 & 14,53 \\
Persediaan & 160.514 .808 .289 .624 & 123.450 .089 .924 .835 & 30,02 \\
Jumlah & 665.161 .112 .767 .725 & 491.867 .510 .128 .337 & 35,23 \\
\hline
\end{tabular}

(Sumber: Kemenkeu, LKPP, 2020: 183) 
Data Badan Pusat Statistik (BPS) mencatat jumlah penduduk dari tahun ke tahun mengalami peningkatan. Hasil sensus penduduk (SP2020) pada September 2020 mencatat jumlah penduduk sebesar 270,20 juta jiwa. Jumlah penduduk hasil SP2020 bertambah 32,56 juta jiwa dibandingkan hasil SP2010. Laju pertumbuhan penduduk per tahun selama 2010-2020 rata-rata sebesar 1,25 persen (BPS, 2020: 9). Hal ini menandakan bahwa Indonesia mempunyai peluang besar untuk memberantas keberadaan korupsi melalui pemberdayaan peran dan strategi masyarakat secara keseluruhan.

Masyarakat menurut Kontjaraningrat (2009: 116) merupakan sekumpulan manusia yang saling bergaul dan saling berinteraksi. Masyarakat terdiri atas beberapa unsur diantaranya (1) beranggotakan minimal dua orang, (2) anggotanya sadar sebagai satu kesatuan, (3) berkomunkasi dan membuat aturan-aturan antaranggota masyarakat, serta (4) menjadi sistem hidup bersama yang menimbulkan kebudayaan dan keterkaitan satu dengan lainnya. Ahli sosiologi Amerika Coleman (1998) dalam (Tamboto, \& Manongko, 2019) mengatakan bahwa masyarakat bukan entitas tunggal, tetapi berbagai entitas yang berbeda, memiliki dua karakteristik yang sama: mereka semua terdiri dari beberapa aspek struktur sosial dan mereka memfasilitasi tindakan tertentu dari individu yang di dalam struktur.

Masyarakat yang baik (good community) memiliki sembilan nilai, meliputi: (1) setiap anggota memiliki hubungan pribadi (interaksi), (2) komunitas memiliki otonomi, kewenangan, dan kemampuan mengurus urusannya sendiri, (3) memiliki viabilitas yaitu kemampuan memecahkan masalahnya sendiri, (4) berkesempatan yang sama dan bebas menyatakan kehendaknya, (5) berpartisipasi aktif dalam mengurus kepentingan bersama, (6) komunitas memberi makna untuk, (7) adanya heterogenitas dan perbedaan pendapat, (8) pelayanan masyarakat ditempatkan sedekat dan secepat mungkin pada yang berkepentingan, (9) memiliki kemampuan dalam managing conflict.

Berdasarkan Undang-Undang Nomor 30 Tahun 2002 tentang Komisi Pemberantasan Tindak Pidana Korupsi Pasal 1 butir ke-3, pemberantasan tindak pidana korupsi adalah serangkaian tindakan untuk mencegah dan memberantas tindak pidana koruspsi melalui upaya koordinasi, supervisi, monitor, penyelidikan, penyidikan, penuntutan, dan pemeriksaan di sidang pengadilan, dengan peran serta masyarakat berdasarkan peraturan perundang-undangan yang berlaku. Dengan demikian, masyarakat memiliki peran dalam memerangi korupsi. Adapun beberapa peran masyarakat dalam pemberantasan korupsi sebagai berikut.

Sesuai dengan UUD NRI Tahun 1945 pasal 1 ayat (2) menyebutkan bahwa kedaulatan sepenuhnya berada di tangan rakyat dan wajib dijalankan sesuai dengan Undang-Undang Dasar 1945. Prinsip ini sesuai dengan prinsip supremasi hukum dan kedaulatan rakyat (Huda, 2007: 62). Efektivitas penegak hukum dalam korupsi tidak hanya diciptakan oleh lembaga pemerintah. Sejatinya masyarakat yang proaktif sangat berperan penting dalam pencegahan perilaku korupsi. Adapun beberapa strategi yang bisa dilakukan yaitu pertama, mengenal korupsi untuk perbaikan 
birokrasi. Masyarakat perlu mengambil bagian untuk benar-benar mengenal segala sesuatu yang berkaitan dengan tindak pidana korupsi. Masyarakat harus bisa membiasakan diri mengurus segala sesuatu melalui birokasi yang benar dan tidak mencari jalan pintas. Masyarakat tidak perlu segan dan takut dalam menegur institusi penegak hukum. Hal ini menjadikan Aparatur Sipil Negara untuk kembali pada fitrahnya sebagai lembaga pelayan yang berjalan dengan integritas yang baik. Hal ini sesuai dengan harapan normatif dalam Peraturan Menteri Pendayagunaan Aparatur Negara dan Reformasi Birokrasi Republik Indonesia Nomor 60 Tahun 2020 tentang Pembangunan Integritas Pegawai Aparatur Sipil Negara.

Kedua, mengetahui hak dan kewajiban sebagai warga negara yang cerdas dan baik. Masyarakat yang cerdas tentu dapat ditempuh dengan berbagai cara. Salah satu metode yang dapat diambil yaitu dengan mengakses berbagai pengetahuan pada laman birokrasi pemerintah yang telah disediakan. Adanya media berbasis internet pada dasarnya mempermudah kita dalam menambah pengetahuan yang kita butuhkan. Misalnya, dalam hal hajat tertentu, masyarakat harus bisa mengakses beberapa persyaratan yang dibutuhkan bukan memilih instan dengan memanfaatkan jasa calo. Tindakan ini selain memberikan kecerdasan masyarakat sebelum bertindak, tetapi juga menjadi dasar dalam menggunakan hak dan kewajibannya secara baik dan cerdas. Hal ini sesuai dengan yang disampaikan Maftuh dan Sapriya (2005: 30) bahwa masyarakat yang bertanggung jawab dan mampu berpartisipasi dalam kehidupan merupakan bagian dari warga negara yang memiliki kecerdasan (civic intelegence) dan tanggung jawab (civic responsibility).

Ketiga, kerja sama dan komitmen yang utuh. Pemberantasan korupsi memerlukan kerja sama yang baik antaranggota masyarakat di seluruh wilayah negara. masyarakat dalam suatu wilayah yang tingkat korupsinya lebih kecil dapat membantu di wilayah lain untuk memberantas korupsi secara utuh. Misalnya, dengan memanfaatkan teknologi atau pendidikan jarak jauh berbasis internet masyarakat bisa berdiskusi dengan masyarakat lainnya melalui grup yang disediakan. Pendidikan jarak jauh sendiri telah diatur dalam UU Sisdiknas No. 20 Tahun 2003 yaitu merupakan kegiatan yang dilaksanakan semua jalur, jenjang, dan jenis pendidikan. Adanya pertukaran informasi ini, masyarakat bisa melakukan pendidikan antarmasyarakat sehingga bisa diajak kerja sama demi tegaknya komitmen secara menyeluruh dalam upaya pendidikan dan bertukar strategi dalam memberantas korupsi.

\section{Peran dan Strategi Sekolah dalam Pendidikan Antikorupsi}

Tindakan korupsi merupakan perbuatan yang tercela dan melanggar norma hukum yang berlaku di Indonesia, serta dapat merusak citra bangsa dan negara Indonesia. Berbagai tindakan korupsi di negara Indonesia serta negara-negara yang kedapatan melakukan tindakan korupsi (Halimah, dkk, 2021: 1-14). Banyak tindakan korupsi yang ada di setiap kegiatan kehidupan masyarakat, bahayanya dapat menular dan berdampak tidak baik kepada generasi muda. Tindakan korupsi menurut (Kusumawati, dkk, 2020: 2492) merupakan kejahatan kerah putih yang sulit diberantas, perlu tindakan yang serius aparat penegak hukum yang profesional dan berkualitas. 


\section{AoEJ: Academy of Education Journal}

Vol. 13 No 1 Tahun 2022

Pendidikan antikorupsi sekiranya diajarkan kepada pelajar atau peserta didik di sekolah yang merupakan generasi muda harapan bangsa. Pendidikan adalah sebagai upaya pembentukan karakter bangsa sebagai usaha mewujudkan tatanan perbaikan kehidupan masyarakat, berbangsa, dan bernegara. Pendidikan antikorupsi di sekolah perlu untuk diselenggarakan supaya bermanfaat agar siswa atau peserta didik memiliki nilai-nilai antikorupsi yang dapat diimplementasikan dalam kehidupan sehari-hari baik sebagai makhluk pribadi ataupun makhluk sosial di sekolah, keluarga, dan masyarakat.

Nilai-nilai yang ada dalam pendidikan antikorupsi yang dirumuskan Komisi Pemberantasan Korupsi (KPK) telah dirumuskan dalam sembilan nilai antikorupsi untuk dapat ditanamkan pada peserta didik (Febriani, 2020: 1). Nilai-nilai antikorupsi yang dirumuskan dalam tiga nilai yaitu nilai inti, nilai sikap dan nilai etos kerja. Nilai yang pertama yaitu nilai inti terdiri dari nilai-nilai kejujuran, kedisiplinan, dan tanggung jawab. Nilai yang kedua adalah nilai sikap terdiri dari nilai adil, berani, dan peduli. Nilai ketiga yaitu nilai etos kerja terdiri dari nilai kerja keras, sederhana, dan mandiri.

Nilai-nilai pendidikan antikorupsi yang ada pada ketiga nilai-nilai antikorupsi tersebut tentunya perlu ditanamkan pada peserta didik di sekolah serta diharapkan dapat diimplementasikan pada kehidupan dalam keluarga, sekolah, dan masyarakat. Peran sekolah tentunya penting dalam membantu dan mengantarkan peserta didik dalam mengembangkan karakter melalui pendidikan antikorupsi di sekolah. Strategi sekolah dalam mengantarkannya dengan menambahkan kurikulum pendidikan antikorupsi dalam mata pelajaran yang diajarkan di sekolah. Sekolah akan lebih mudah dalam mengembangkan karakter peserta didik dengan merancang modul pendidikan antikorupsi yang dijadikan acuan bahan ajar dalam pembelajaran di kelas. Dalam pembuatan modul juga diharapkan kerja sama dari beberapa pihak yaitu guru, kepala sekolah, serta tim penyusun kurikulum. Dalam implementasi penerapan pengembangan karakter melalui pendidikan antikorupsi di sekolah dibutuhkan sinergi antara sekolah, orang tua, dan masyarakat supaya tujuan pendidikan antikorupsi tercapai. Di sini peran sekolah sangatlah penting, dengan kerja sama serta sinergi antara sekolah, orang tua, dan masyarakat akan dapat membantu peserta didik dalam mengaktualisasikan nilai-nilai antikorupsi di lingkungan sekitar.

Nilai-nilai pendidikan antikorupsi yang dapat diajarkan serta dikembangkan kepada peserta didik. Pertama, nilai-nilai inti yaitu (1) nilai-nilai kejujuran, nilai kejujuran bisa diterapkan peserta didik dalam segala hal, khususnya diterapkan pada diri sendiri serta umumnya kepada orang lain. Peserta didik diharapkan bisa mengidentifikasi karakter jujur dan dapat menghayati manfaat karakter jujur. Peserta didik dapat menyadari pentingnya memupuk serta memelihara karakter jujur. Nilai kejujuran dapat diterapkan dalam lingkungan anak-anak sehingga diharapkan akan memiliki jiwa integritas; (2) nilai kedisiplinan, diharapkan peserta didik dapat mengindentifikasi karakter disiplin supaya mengarahkan pribadinya sebagai kunci menuju kesuksesan hidupnya. Dengan membangun karakter disiplin maka dapat menghayati dan menyadari betapa pentingnya 


\section{AoEJ: Academy of Education Journal}

Vol. 13 No 1 Tahun 2022

memupuk dan memelihara karakter disiplin sebagai karakter utama yang bisa mengantarkan seseorang menjadi pribadi serta pemimpin yang sukses; (3) nilai tanggung jawab, diharapkan peserta didik bisa menjelaskan dan menyadari bagaimana dapat membangun karakter tanggung jawab serta dapat melaksanakan sikap tanggung jawab sebagai bentuk karakter. Peserta didik diharapkan juga dapat menerima tanggung jawab baik di rumah, sekolah, maupun masyarakat. Menurut Wijaya (Kuswati, 2019: 78) budaya yang diciptakan di sekolah dalam bentuk lingkungan yang jujur, disiplin, adil, mandiri, berani, kerja keras, peduli, bertanggung jawab, sederhana, dan bermartabat.

Nilai yang kedua yaitu nilai sikap terdiri dari (1) nilai adil, peserta didik diharapkan dapat menjelaskan pentingnya berlaku adil dan menyadari pentinya berbuat adil dan bertindak adil dalam segala situasi dan kondisi. Peserta didik dapat mengetahui dan dapat melakukan sikap adil dalam kehidupannya dan bagaimana bersikap adil yang akan membawa perubahan dan membawa kebaikan kepada siapa saja yang melakukannya; (2) nilai berani, peserta didik dapat menyadari pentingnya melakukan tindakan berani dalam perbuatan dan tindakan guna menegakkan nilai-nilai kebenaran. Dapat mendorong dan membangun seseorang untuk bertindak berani dan selalu menjadi seseorang yang memiliki sikap yang berani dan benar serta dapat menampilkan tindakan berani dalam kebenaran dalam kehidupan sehari-harinya; (3) nilai peduli, yaitu peserta didik dapat mengidentifikasi perilaku peduli terhadap aturan yang berlaku serta menyadari betapa pentinya tindakan berperilaku peduli, baik peduli terhadap dirinya, keluarganya, gurunya, teman-temannya di sekolah dan orang-orang di sekitarnya. Nilai peduli dengan membangun tindakan peduli pada dirinya dan orang lain sehingga mendorong dirinya menjadi pribadi yang peduli dengan kebaikan serta kebajikan di manapun dia berada.

Nilai ketiga yaitu nilai etos kerja yaitu (1) nilai kerja keras, peserta didik dapat membaca dan menyadari pentingnya menjadi pribadi yang ulet, tangguh dan pekerja keras dalam segala hal, khususnya dalam pencapaian cita-citanya. Membangun sikap kerja keras dan berjuang supaya menjadi pejuang yang ulet serta tangguh agar tercapai tujuannya, serta menyadari kerja keras dan usahanya dalam kehidupannya; (2) nilai sederhana, peserta didik dapat menyadari serta dapat menunjukkan karakter hidup sederhana tidak boros dan konsumtif. Dapat melaksanakan segala aktivitas dan kegiatannya dengan kegiatan yang mencerminkan hidup sederhana serta menyadari pentingnya manfaat karakter sederhana. Menjadi pribadi yang dapat mendukung pola hidup sederhana sebagai karakter diri serta menghayati pentingnya hidup sederhana dan dapat menerapkan pola hidup sederhana; (3) nilai mandiri, peserta didik dapat membaca pentingnya kepribadian mandiri dan menyadari pentingnya seseorang memiliki kepribadian mandiri. Peserta didik dapat menerapkan bentuk hidup mandiri dan kemandirian yang terbentuk dari keadaan dan pengalamannya. Mengetahui bahwa kemandirian dapat dibentuk dari keadaan ataupun kondisi apapun dalam kehidupan yang dilaluinya. Serta dapat menerima dan melakukan sikap mandiri tersebut dalam setiap keadaan, kapanpun dan dimanapun dia berada. 
Ketiga nilai yang mesti dimiliki peserta didik tersebut dapat mengantarkan peserta didik menjadi pribadi yang berkarakter, serta memiliki dedikasi tinggi dalam segala hal dan keadaan situasi apapun. Sekolah dapat membimbing peserta didik untuk mengetahui, sadar, serta memahami tentang tindakan atau perilaku antikorupsi. Dengan melakukan nilai-nilai antikorupsi dalam praktik atau aktivitas kehidupan sehari-hari baik di sekolah atau di luar sekolah melalui melihat, mendengar dari guru, orang tua, teman, tokoh masyarakat, juga membaca dari berbagai media, merasa serta tindakan yang nyata melalui pengalaman langsung ataupun tidak langsung, maka peserta didik akan memiliki karakter atau nilai-nilai antikorupsi. Peserta didik dikondisikan untuk membiasakan diri dengan menunjukkan sikap, perilaku, serta aktivitas antikorupsi dalam kehidupan nyata. Tentunya proses pembiasaan ini tidaklah mudah, perlu waktu, tindakan serta keteraturan sikap atau penerapan nilai-nilai antikorupsi agar tercapai tujuan pendidikan antikorupsi tersebut. Di sini dituntut adanya sinergi antara sekolah yang bertindak sebagai lokomotif atau penggerak untuk dapat bekerja sama dengan pihak keluarga dan juga masyarakat.

Strategi pendidikan antikorupsi yang dapat dilakukan di sekolah dengan cara melakukan pengembangan model pembelajaran PPKn antikorupsi berbasis lingkungan melalui cooperative learning. Seperti yang dilakukan oleh Nuryati, dkk., (2017: 27) dimulai dari pendahuluan yaitu salam dan berdoa, menanyakan kabar siswa, ice breaking, pemberian motivasi (nilai antikorupsi: jujur, tanggung jawab, disiplin, dan peduli). Dilanjutkan tahap inti pembelajaran yaitu: penyajian secara umum, pengajuan membandingkan dan menjelaskan analogi, analogi tim, dan pengajuan analogi baru (nilai antikorupsi: jujur, tanggung jawab, disiplin, dan peduli). Terakhir yaitu penutup meliputi konfirmasi, simpulan, dan tindak lanjut pertemuan berikutnya. Strategi sekolah dalam pendidikan antikorupsi tentunya akan dapat dilaksanakan apabila semua pihak saling bersinergi agar terciptanya karakter antikorupsi. Pihak sekolah dalam hal ini kepala sekolah hendaknya dapat menyusun rencana implementasi pendidikan antikorupsi bersama guru, serta dapat melakukan kegiatan evaluasi terhadap kegiatan yang telah dilaksanakan (Widodo, 2017: 35). Guru ataupun pengajar memberikan pendidikan dan mengajaran yang baik dan bijaksana serta sesuai minat bakat serta keterampilan peserta didiknya. Sekolah bekerja sama dengan komite sekolah dan masyarakat saling memberikan dukungan serta pengawasan kepada peserta didik, baik di sekolah ataupun di luar lingkungan sekolah. Kristiono (2019: 2017) menjelaskan bahwa pendidikan antikorupsi di luar pembelajaran dapat ditanamkan melalui kegiatan ekstrakurikuler, misalnya: pramuka dan paskibra.

\section{Peran dan Strategi Negara dalam Pendidikan Antikorupsi}

Korupsi sebagai salah satu tindak pidana khusus, dapat dikategorikan sebagai extra ordinary crime (Ifrani, 2017: 319). Tindak pidana korupsi bersifat tindak pidana yang luar biasa (extra ordinary crimes) karena bersifat sistemik, endemik yang berdampak sangat luas (systematic dan widespread) yang tidak hanya merugikan keuangan negara tetapi juga melanggar hak sosial dan ekonomi masyarakat luas... (Ifrani, 2017: 321) . Untuk itu negara harus menjalankan peran dan strateginya dalam pendidikan antikorupsi, agar tindak pidana korupsi dapat dicegah sedari awal. 
Pengertian negara dalam artikel ini, sebagaimana merujuk pada pendapat Logemen (dalam Usman, 2015: 133). Negara adalah suatu organisasi kemasyarakatan yang bertujuan dan dengan kekuasaannya mengatur dan mengurus suatu masyarakat tertentu. Negara dalam hal ini yaitu pemerintah sebagai pemangku kebijakan dan lembaga lain yang terlibat dalam pembuatan kebijakan. Pemerintah memiliki peran untuk merumuskan pendidikan antikorupsi dalam skala yang lebih luas. Sebab, negaralah yang memiliki kekuasaan untuk mengendalikan lembaga formal maupun nonformal untuk melaksanakan pendidikan antikorupsi.

Beberapa hal yang dapat dilakukan negara dalam melaksanakan pendidikan antikorupsi yaitu: pertama, membumikan budaya malu terhadap seluruh pejabat dan pegawai pemerintahan mulai dari pusat sampai daerah. Sikap malu merupakan identitas dari budaya Timur, yang tercermin dalam diri orang Melayu, sifat pemalu di sini bukanlah rendah diri, melainkan malu untuk melakukan tindakan yang melanggar hukum (Sulistyawati \& Purba, 2019: 440). Dalam konteks pendidikan antikorupsi khususnya Indonesia sebagai negara timur, nilai budaya malu ini harus diinternalisasikan kepada seluruh pejabat pemerintah dan seluruh aparatur sipil negara yang memiliki kesempatan untuk melakukan tindak pidana korupsi. Membumikan budaya malu dapat dilakukan dengan dua pendekatan. Pendekatan pertama dengan membiasakan budaya malu melalui diklat-diklat formal sebagai prasyarat menjadi pejabat pemerintahan dan Aparatur Sipil Negara (ASN). Pendekatan pertama ini, harus menekankan pada proses menuju spiritual accountability agar pejabat pemerintah maupun pegawai pemerintahan memiliki budaya malu yang tingi untuk mendekat apalagi melakukan tindak pidana korupsi. Sebab mereka yang memiliki spiritual accountability akan selalu ingat pada perjanjian Tuhannya, yang pada dasarnya merupakan tujuan hidup dan kesadaran bahwa hidup mereka harus dipertanggungjawabkan (Tim Penyusun Modul KPK, 2015: 19). Pendekatan kedua yaitu dengan memberikan sanksi sosial agar pelaku tindak pidana korupsi, malu atas tindakannya. Sanksi sosial dapat dijadikan alternatif agar pejabat pemerintah dan pegawai pemerintahan sadar bahwa korupsi merupakan tindakan yang 'memalukan'. Sanksi sosial ini dapat berupa penayangan daftar pelaku korupsi melalui media nasional dalam jangka waktu tertentu. Pihak yang dapat mengatur sanksi sedemikian rupa yaitu negara, dalam hal ini pemerintah bersama dengan lembaga legislatif. Negara harus memiliki komitmen untuk membumikan budaya malu, untuk mempermalukan pelaku tindak pidana korupsi melalui dasar aturan hukum yang khusus.

Kedua, memasukkan pendidikan antikorupsi pada pendidikan dasar dan pendidikan tinggi. Membudayakan antikorupsi di Indonesia membutuhkan waktu yang tidak sebentar. Mengingat saat ini kebiasaan koruptif seringkali terjadi dalam berbagi sektor baik dalam bentuk pungli, suap, menggelapkan uang, maupun tindakan koruptif lainnya. Selain itu, korupsi merupakan sebuah tindakan yang berkenaan dengan karakter yang buruk, sehingga perlu proses pembentukan karakter yang panjang untuk membentuk budaya dan karakter antikorupsi. Untuk itu, penting rasanya 
negara mengambil peran untuk memasukkan pendidikan antikorupsi dalam kurikulum pendidikan formal, mulai dari SD (Sekolah Dasar) sampai dengan perguruan tinggi.

Berdasarkan konsep yang dirumuskan oleh Komisi Pemberantasan Korupsi (KPK), ada sembilan nilai dasar yang perlu diaktualisasikan dalam pendidikan antikorupsi di sekolah, meliputi: nilai kejujuran, hidup sederhana, adil, berani, tanggung jawab, kerja keras, hemat, disiplin, dan mandiri. Nilai-nilai tersebut sudah tercermin dalam masyarakat sejak zaman dulu, dan secara eksplisit tercantum dalam falsafah negara, namun tergerus oleh gaya konsumerisme akibat arus globalisasi dan modernisasi (Montessori, 2012: 295). Dalam konteks pendidikan antikorupsi, secara teoretis siswa yang belajar nilai-nilai antikorupsi akan tergerak mendalami materi ketika mengetahui dan sadar bahwa apa yang mereka alami sehari-hari ternyata memposisikan mereka sebagai korban dari praktik korupsi (Subkhan, 2020: 20).

Dengan mereka memahami nilai dan memosisikan diri sebagai korban dalam praktik korupsi, diharapkan kurikulum pendidikan antikorupsi tidak sekadar tekstual namun juga kontekstual. Pendidikan antikorupsi bukanlah semata-mata seperangkat aturan perilaku yang dibuat oleh seseorang dan harus diikuti oleh orang lain. Seperti dengan kejahatan lainnya, korupsi juga sebuah pilihan artinya bisa dilakukan atau dijauhi. Pendidikan mulai dari dasar sampai ke pendidikan tinggi pada dasarnya yaitu mengkondisikan agar perilaku siswa sesuai dengan tuntutan masyarakat serta memiliki keyakinan yang utuh bahwa korupsi merupakan suatu kejahatan. Sarmini, et al. (2017: 2) menjelaskan bahwa pendidikan sangat berpengaruh dalam pencegahan korupsi, yaitu dengan menyediakan materi pendidikan antikorupsi kepada anak muda untuk membangun budaya antikorupsi.

Ketiga, merumuskan sanksi sosial yang ideal terhadap tindak pidana korupsi. Idealnya untuk sebuah kejahatan yang luar biasa dengan dampak negatif yang luas, sanksi untuk tindak pidana korupsi mestinya dapat memberikan efek jera bagi seluruh oknum yang hendak melakukannya. Selain meberikan efek jera mestinya sanksi bagi pelaku tindak pidana korupsi harus memberikan efek yang mendidik agar tindak pidana korupsi dapat di cegah dari awal. Sanksi sosial dapat menjadi salah satu alternatif untuk mendidik masyarakat bahwa tindakan korupsi merupakan suatu kejahatan yang memalukan untuk dilakukan. Sanksi sosial diharapkan mampu memberikan efek jera yang muncul dari penalaran moral dari pelaku korupsi (Aerlang, dkk., 2016: 179). Sanksi sosial ini dapat berupa penayangan program khusus bagi pelaku korupsi, dengan memanfaat media massa dan televisi milik pemerintah maupun kerja sama dengan pihak swasta. Hal ini untuk mempertegas bahwa perilaku tindak pidana korupsi merupakan perilaku yang tidak bermoral dan merugikan masyarakat secara luas. Selain itu penting untuk menumbuhkan nilai sosial untuk menegaskan integritas dan membenci korupsi (Huang, 2021: 276).

Pendidikan antikorupsi pada anak diberikan melalui orang tua melalui panutan, dilanjutkan melalui oleh pihak sekolah sebagai bagian dari kurikulum tersembunyi yang dicontohkan oleh lingkungan sekolah. Dukungan pemerintah daerah dan pusat melalui payung hukum diperlukan 
untuk melaksanakan pendidikan antikorupsi di semua tingkat pendidikan (Anienda TF., \& Permatasari, 2019: 1166). Semua lingkungan berpartisipasi aktif dalam mewujudkan perilaku antikorupsi agar kasus korupsi tidak merajalela setiap tahun di Indonesia.

\section{SIMPULAN}

Pendidikan antikorupsi dalam lingkungan keluarga, sekolah, masyarakat, dan negara perlu diwujudkan secara normatif ataupun praktis. Keempat lingkungan tersebut merupakan unsur yang saling berhubungan dan tidak bisa dipisahkan dengan lainnya. Keluarga memiliki peran dalam mendidik anak-anak melalui keteladanan, pembiasaan, dan dialog. Keluarga juga perlu memaksimalkan fungsi keagamaan, sosial-budaya, sosialisasi dan pendidikan, serta ekonomi. Selanjutnya, masyarakat perlu mengenal korupsi untuk perbaikan birokrasi, mengetahui hak dan kewajiban sebagai warga negara yang cerdas dan baik, kerja sama dan komitmen yang utuh. Sekolah perlu merancang modul pembelajaran dengan mengembankan nilai-nilai antikorupsi, seperti nilai inti, nilai sikap, dan nilai etos kerja. Strategi yang dilakukan sekolah yaitu pengembangan model pembelajaran PPKn antikorupsi berbasis lingkungan melalui cooperative learning. Negara perlu menerapkan budaya malu di lingkungan pemerintahan, memasukkan pendidikan antikorupsi di pendidikan dasar sampai dengan pendidikan tinggi, dan merumuskan sanksi sosial dalam tindak pidana korupsi. Beberapa peran dan strategi tersebut diharapkan mampu mencegah secara dini dan komprehensif dalam menanggulangi korupsi yang dianggap 'kebiasaan' di masyarakat, dunia politik, dan lingkup pemerintahan. Sinergisitas diperlukan oleh stakeholder untuk mewujudkan budaya antikorupsi sehingga mampu membawa peradaban yang lebih maju dan berbudi luhur.

\section{SARAN}

Pendidikan antikorupsi hendaknya sudah mulai diajarkan sejak diri, ketika seorang anak mendapatkan pendidikan sejak dini, baik di lingkungan keluarga, sekolah dan sekitarnya. Masyarakat perlu berperan dalam mendukung gerakan anti korupsi yang telah dicanangkan pemerintah dengan slogannya "Pemerintah yang bersih dari korupsi dan nepotisme". Perlu adanya sinergi dari semua pihak agar tujuan kesejahteraan masyarakat Indonesia tercapai. Penulis merekomendasikan pada penelitian-penelitian selanjutnya tentang pendidikan antikorupsi agar bisa mencarikan jalar keluar pada permasalahan bangsa terkait masalah korupsi. 


\section{DAFTAR PUSTAKA}

Aerlang, M., dkk. 2016. Membangun sanksi psikososial bagi terpidana kasus korupsi. Jurnal Integritas, 2(1), 175-189.

Alfurkan \& Marzuki. 2019. Penguatan nilai kejujuran melalui pendidikan antikorupsi di sekolah. Jurnal Ilmiah Pendidikan Pancasila dan Kewarganegaraan, 4(2), 221-231.

Anienda TF., M, \& Permatasari. 2019. Anti-corruption values planting based education formulation for children as effort to prevent corruption. Advances in Social Science, Education and Humanities Research, volume 383, 2nd International Conference on Social Science (ICSS 2019).

Atmadja, A. T. 2015. Habituasi sebagai model pendidikan antikorupsi di lingkungan keluarga. Jurnal Ilmiah Akuntansi dan Bisnis, 10(2), 80-88.

Badan Pusat Statistik. 2020. Hasil sensus penduduk 2020. Sumber: https://www.bps.go.id/website

BPS (Badan Pusat Statistika). 2021. Perkembangan IPAK 2012-2021. https://www.bps.go.id/pressrelease/2021/06/15/1847/indeks-perilaku-anti-korupsi--ipak-indonesia-2021-meningkat-dibandingkan-ipak-2020.html

Budiman, A. 2021. KPK sebut sector swasta dan dpr dominasi kasus korupsi. https://nasional.tempo.co/read/1488894/kpk-sebut-sektor-swasta-dan-dpr-dominasi-kasuskorupsi/full\&view $=\mathrm{ok}$

Febriani, R. 2020. Modul pendidikan antikorupsi mata pelajaran muatan lokal untuk SMP/MTs Kelas IX. Bandar Lampung: Dinas Pendidikan dan Kebudayaan Kota Bandar Lampung.

Halimah, L., Fajar, A., \& Hidayah, Y. 2021. Pendidikan anti korupsi melalui mata kuliah Pancasila: tingkatan dalam memahami kejujuran. Jurnal Pendidikan Kewarganegaraan, 5(1), 1-14.

Handoyo, E. 2021. Anti-corruption education at Universitas Negeri Semarang: what benefits can students get? Turkish Journal of Computer and Mathematics Education, 12(6).

Hasanah, S.U., et al. 2019. College policies in implementing anti-corruption education. Advances in Social Science, Education and Humanities Research, volume 418 2nd Annual Civic Education Conference (ACEC 2019).

Huda, N. 2007. Lembaga negara dalam masa transisi demokrasi. Yogyakarta: UII Press.

Huang, C. H., et al. 2021. Effect of applying case method to anti-corruption education on learning motivation and learning effectiveness. Revista de cercetare şi intervenție socială. Vol. 73, 276-287. https://doi.org/10.33788/rcis.73.17

Ifrani. 2017. Tindak pidana korupsi sebagai kejahatan luarbiasa. Jurnal al'adl, 9(3), 319-336.

Isgiyanti, M. dkk. 2016. Pengaruh pemahaman nilai-nilai Pancasila dan pendidikan dalam keluarga terhadap sikap antikorupsi pada siswa MAN 2 Jember. Jurnal Pendidikan dan Humaniora, 52(1), 26-32.

Kamil, I. 2021. Pandemi pun tak hentikan munculnya kasus korupsi. https://nasional.kompas.com/read/2021/07/14/19255121/pandemi-pun tak hentikanmunculnya-kasus-korupsi?page $=$ all

Kemenkeu. 2020. Laporan Keuangan Pemerintah Pusat Tahun 2020 (Audited). https://www.kemenkeu.go.id

Koentjaraningrat. 2009. Pengantar ilmu sosiologi. Jakarta: Rineka Cipta.

KPK. 2015. Antikorupsi: modul diklat prajabatan. Jakarta: Lembaga Administrasi Negara. 
Kristiono, N., et al. 2019. The Implementation of Anti-Corruption Education in Texmaco Vocational High School Pemalang. Advances in Social Science, Education and Humanities Research, volume 418 2nd Annual Civic Education Conference (ACEC 2019).

Montessori, M. 2012. Pendidikan antikorupsi sebagai pendidikan karakter di sekolah. Jurnal Demokrasi, 12(1), 293-301.

Kusumawati I, Supriyono, Atmadja IS, Hasanah E, \& Cahyati S. 2020. The role of law enforcement agencies in the effort of corruption prevention and eradication in the perspective of progressive law in Indonesia. International Journal of Psychosocial Rehabilitation, 24(3), 2492-2501. DOI: 10.37200/IJPR/V24I3/PR201895.

Kuswati, M. 2019. Development of financial literacy and anticorruption education in Primary Schools through storytelling activities. International Journal of Science and Applied Science: Conference Series, 3(1). doi: 10.20961/ijsascs.v3i1.32468

Muhammad, F. S. 2006. Peran serta masyarakat dalam pemberantasan korupsi untuk mewujudkan pemerintah yang baik dan bersih. Tesis. Surakarta: Universitas Muhammadiyah Surakarta.

Nuryati, N., Budiutomo, T., \& Bowo, A. N. 2017. Pengembangan model pembelajaran PPKn antikorupsi berbasis lingkungan melalui cooperative learning di SMA/SMK swasta Kulon progo Yogyakarta. Academy of Education Journal, 8(1), 27-49. https://doi.org/10.47200/aoej.v8i1.333.

Peraturan Menteri Pendayagunaan Aparatur Negara dan Reformasi Birokrasi Republik Indonesia Nomor 60 Tahun 2020 tentang Pembangunan Integritas Pegawai Aparatur Sipil Negara.

Putra, I. A. 2018. Pola asuh otoriter demokratis dalam menanamkan pendidikan anti korupsi. Sosietas, 8(1), 485-489.

Putri, B. U. 2019. Pasal-pasal Revisi UU KPK yang potensial lemahkan KPK. https://nasional.tempo.co/read/1249932/pasal-pasal-revisi-uu-kpk-yang-potensial-lemahkan$\mathrm{kpk} /$ full\&view $=\mathrm{ok}$

Ratnasari, A. D. \& Sarmini. 2017. Konstruksi orangtua dalam menanamkan pendididkan antikorupsi pada anak. Kajian moral dan kewarganegaraan, 05(03), 425- 440.

Rawanoko, E. S. et al. 2019. Building an anti-corruption civilization through education. Advances in Social Science, Education and Humanities Research, volume 418, 2nd Annual Civic Education Conference (ACEC 2019).

Rofiq, M. 2021. 17 tersangka kasus korupsi bupati probolinggo diperiksa di polres. https://news.detik.com/berita-jawa-timur/d-5708289/17-tersangka-kasus-korupsi-bupatiprobolinggo-diperiksa-di-polres.

Sarmini, et al. 2017. The importance of anticorruption education teaching materials for the young generation. The 2nd International Joint Conference on Science and Technology (IJCST) 2017. doi :10.1088/1742-6596/953/1/012167.

Sulistyawati, S., \& Purba, N. 2019. Strategi pencegahan korupsi dengan budaya malu (Studi komparatif masyarakat Melayu Indonesia dengan Jepang): Jurnal Penelitian Pendidikan Sosial Humanior, 4(1), 439-447.

Suryandari, 2021. Korupsi di Indonesia sudah ada sejak era voc. https://mediaindonesia.com/politik-dan-hukum/400591/korupsi-di-indonesia-sudah-adasejak-era-voc.

Syahuri, T. 2021. KPK pasca revisi Undang-Undang KPK. PPT disampaikan dalam Webinar Prodi PPKn FIS UNY pada tanggal 4 Agustus 2021.

Syarif, Z., et al. 2020. Strategy of strengthening corruption prevention and enforcement through social punishment: A Sociological study. Test Engineering \& management, 83, 1218012192. 
Subkhan, E. 2020. Pendidikan Anti Korupsi perspektif pedagogis kritis. Jurnal Anti Korupsi, 6(1), $15-30$.

Tamboto, H. J., \& Manongko, A. A. 2019. Model pengentasan kemiskinan masyarakat Pesisir: berbasis literasi ekonomi dan modal sosial. Malang: Seribu Bintang.

Taufiqurrahman, F. 2021. Selewengkan dana desa saat masih menjabat, mantan Kades di Cianjur jadi tersangka Tipikor", https://regional.kompas.com/read/2021/06/07/181031678/selewengkan-dana-desa-saatmasih-menjabat-mantan-kades-di-cianjur-jadi.

Thoomaszen, F. W., \& Tameon, S. M. 2018. Parental participation in providing anti-corruption education to children as an effort to prevent corruption in the city of Kupang. Asia Pasific Fraud Journal, 3(2), 201-212.

Undang-Undang Dasar Negara RI Tahun 1945.

Undang-Undang Nomor 30 Tahun 2002 tentang Komisi Pemberantasan Tindak Pidana Korupsi.

Undang-Undang RI No. 20 Tahun 2003 tentang Sistem Pendidikan Nasional.

Usman. 2015. Negara dan fungsinya (telah pemikiran politik). Jurnal: Al-daulah, 4(1), 130-139.

Utami, M. N., dkk. 2016. Pengaruh pendidikan karakter anti korupsi dalam keluarga terhadap karakter anti korupsi pada remaja. JKKP: Jurnal Kesejahteraan Keluarga dan Pendidikan, 3(1), 7-11. http://doi.org/10.21009/JKKP

Waskito M. N., \& Pambudi. D. I. 2018. Penanaman nilai antikorupsi siswa SD melalui pendidikan keluarga di Kampung Prenggan. Fundamental Pendidikan Dasar, 1(3), 173-182.

Widhiasthini, N. W. et al. 2020. The prevention of corruption through the social crime prevention. International Journal of Psychosocial Rehabilitation, 24(03), 2372-2379.

Widodo, S. 2019. Membangun pendidikan antikorupsi di Sekolah Dasar. Jurnal Pendidikan Dasar, 10(1), 35-44. 